\title{
The Lingering Effects of Thought Reform: The Khmer Rouge S-21 Prison Personnel
}

\section{ANGELIKI ANDREA KANAVOU AND KOSAL PATH}

During the Cambodian Genocide (1975-79), about 12,272 to 20,000 people were jailed in the infamous Tuol Sleng (S-21) prison. Only a handful survived. This study focuses on how former S21 perpetrators relate today to their role in the genocide. Through a vast network of fear and torture, the Khmer Rouge instituted a program of "thought reform" in order to accomplish total obedience. Based on court testimonies, archival material, and semi-structured interviews with surviving $S$-21 guards and interrogators, this study shows how the former S-21 personnel manifest a lingering obedience orientation toward authority, limited reflection about the past, and little empathy toward their victims. The study demonstrates the long-lasting implications of the mindset that was established by the Khmer Rouge. More needs to be done to face the past and to "remove the guards from their prisons" in Cambodia.

C ChOlarship has PRovided nEw insights into how ordinary people become perpetrators of genocide (Haritos-Fatouros 2003; Milgram 1974; Waller 2007; Zimbardo 2008). Yet, apart from notable exceptions, far less attention has been placed on perpetrators' post facto perspectives on their actions, as well as their social and psychological adaptation over time (Browning 1992; Hirsch 1995; Klee, Dressen, and Riess 1991). The intensity of large-scale trauma in a society ravaged after the destruction of resources, the disruption of civil society generated by the Khmer Rouge (KR), the Vietnamese occupation of Cambodia in the 1980s, and the lack of accountability afterwards have fragmented Cambodian society. Many survivors and perpetrators have coexisted in conditions of social alienation and confusion about a history that remains unsettled. Unlike the Holocaust, where remembrance is a matter of moral responsibility, remembrance of the Cambodian Genocide is orchestrated in ways that fit the broader political agenda of collective amnesia and disregard for human rights.

This study describes the broader context facing Cambodians during the 1960s and 1970s, such as the Vietnam War (1959-75) and China's Cultural Revolution (1966-76). The influence of these events was especially strong among educated KR cadres. The study begins with an assessment of the cultural background that provided the cultural space from which the KR unleashed their lethal plan. This space enabled a thought reform process across the board in Cambodia. Its results are still felt. In such conditions, "thought reform" practices allowed the KR to effectively forge both willing and unwilling

Angeliki Andrea Kanavou (akanavou@uci.edu) is Tobis Fellow at the Interdisciplinary Center for the Study of Ethics and Morality at the University of California, Irvine.

Kosal Path (kosalpath@brooklyn.cuny.edu) is Assistant Professor in the Department of Political Science at Brooklyn College. 
collaborators, who were frequently recruited as children. Consequently, younger recruits would take relatively less time to forge according to KR standards (Path and Kanavou 2015). Regardless of age, however, through the process of mind control, the KR cadres were able to switch off their consciences in order to commit atrocities in the labor camps (known as killing fields) and elsewhere.

While this study does not seek to vilify agents of state at the time of the genocide and subsequently, it examines the extent to which the collective mindset of the former S-21 staff has endured (Chandler 1999, 32; Keo and Nean 2011). ${ }^{1}$ It seeks to identify shifts from ruleand obedience-based behavior and thinking to genuine assessment of past collective and individual acts. The study focuses on prison guards and interrogators, because they are more likely than other segments of society to still manifest traces of rule-based behavior. Focusing on them will help generate insights into the lingering effects of obedience in other segments of the KR personnel and agents of genocidal acts in other parts of the world. Today, questions remain about the extent to which Cambodians have been able to deal with the past in a way that honors the victims and allows the perpetrators to face their past. In this sense, "historical justice" has not yet been delivered. After all, the results of the genocide are still felt in Cambodia. Socioeconomic injustice perpetuates the collective trauma of the population (Sonis et al. 2009).

Most research in the area of rule- and obedience-based behavior has focused on either the immediate effects of obedience or laboratory tests. Instead, this study looks at such effects decades after the fact. It demonstrates that the ideological and moral frames that were developed during the cadres' extensive thought reform process before and during their work at S-21 prevents them from accepting responsibility for their actions. The main question here is: given the time that has elapsed between the KR rule (1975-79) and today's Cambodia, to what extent might the S-21 personnel have gone from obedient agents to reformed individuals who demonstrate respect for human rights and accept their own wrongdoing?

The effects of lingering obedience are manifested among the former cadres today in the following ways: (1) holding on to definitions of the past-and in particular about what was wrong with former leadership (Lon Nol) and the surrounding conditions (American "imperialism" and Vietnamese "expansionism"); (2) the ambiguity of the situation during the cadres" existence at S-21 — whether they would live or die, and succeed or fail in their tasks; (3) the predominance of emotional responses such as fear and uncertainty that were initially generated and are still in effect, as well as a lack of empathy toward the prisoners; and (4) the ambiguous expression of relief after the cadres' testimonies in the case against Duch.

\section{The S-21 Commandant, Kang Keck Ieu (Alias Duch)}

This study demonstrates the results of these conditions today based on interviews and testimonies in the Extraordinary Chambers in the Courts of Cambodia (ECCC),

\footnotetext{
${ }^{1}$ Based on the amount of biographical forms filled out in February 1977, the number of S-21 personnel was 166 (Chandler 1999, 32). A pair of documents from the Revolutionary Army of Kampuchea General Staff mention the number of staff as being 2,327, "not including components," i.e., prisoners (DC-Cam 1977a, 1977b).
} 
Case 001 (the case against Duch). Given the time that has elapsed since the KR rule (1975-79), to what extent might the S-21 personnel have gone beyond a frame of total obedience to a system of Maoist-inspired ethno-nationalism? The study shows that the lingering obedience of the S-21 cadres today goes far beyond Cambodians' traditional respect for hierarchy. The cadres' narratives demonstrate self-victimization, identification with the regime's ideology, sympathy toward leaders like Duch, heroization of their roles in the revolution, and lack of or limited empathy toward the victims.

The examination of the long-term effects of obedience is facilitated through critical discourse and sociopsychological analysis. Accordingly, this study seeks to reconstruct S-21 personnel's social cognition as a shared social representation of the past and present social reality (Van Dijk 2001, 95). ${ }^{2}$ From this perspective, the thought reform program is assessed as social discursive practices within a closed social institution (S-21), where social cognition was forged and shared by the social collective (S-21 staff). The study examines testimonies before the ECCC of S-21 personnel and semistructured interviews of S-21 personnel of different ranks (one medic, two guards, one chief guard, and one interrogator) who were willing to share their experiences. These texts are covered along three dimensions: (1) induction into the prison system and brainwashing, (2) expression of and type of emotions (or lack thereof) about the system and its people, and (3) their level of reflection during their service at S-21 and today. The answers are indicative of the lasting effects of the obedience mindset. The use of archived confessions allowed the direct connection between expressions of self-criticism and thought reform as part of the S-21 prison routine. Both interviews and testimonies were coded for individuals' feelings and self-assessment regarding their tenure, their superiors, and the justice process itself.

Finally, the testimonies of former S-21 personnel at the ECCC hearing are compared with their accounts of their past involvement before and after the court appearances. The purpose of this comparison is to trace the discursive representation of the personnel's own past actions and choices at S-21. Also, this comparison helps demonstrate the extent to which there are lingering manifestations of obedience-oriented behavior today or they have adopted a new identity and view of the past.

\section{Obedience and Collective Trauma}

The questions that emerge after mass atrocities are about the identities of the perpetrators and explanations for the extent of obedience and the acts of violence that they performed. Natural selection theories tend to emphasize that inborn traits of certain individuals explain why violent individuals end up in positions where violence is the norm (Ferguson and Beaver 2009; Wilson and Daly 1985). While there is merit to the proposition that violence-prone individuals gravitate toward violent subcultures in

\footnotetext{
${ }^{2}$ In particular, we adopted Teun A. Van Dijk’s (2001) Critical Discourse Approach to sociopsychological analysis. Taking "context" seriously, Van Dijk introduces the concept of context models, which are understood as mental representations of the structures of the communicative situation that are discursively relevant for a participant. He names three forms of social representations: knowledge (personal, group, and cultural); attitudes; and ideologies.
} 
any society, inborn traits cannot explain why so many turned genocidaires in Cambodia, Rwanda, Armenia, Germany, and elsewhere. Milgram and others have effectively demonstrated that sadistic behavior occurs even among individuals without sadistic tendencies (Haritos-Fatouros 2003; Milgram 1974; Zimbardo 2008). As this study shows, the personnel selection at S-21 demonstrates the relevance of the obedience literature, with culture-specific explanations in this Southeast Asian context highlighting cultural values regarding obedience, hierarchy, and revenge. Lastly, the selection process expressed the KR's ideological profile as a Maoist-inspired nationalist movement.

Whether violence comes naturally or is committed in the context of obedience and perpetrated or witnessed atrocities, it eventually inflicts heavy moral and psychological consequences on the perpetrator of the violent acts. The ensuing denial at both the collective and the individual levels cements trauma further. Studies on the Holocaust and more focused observations of groups of executioners indicate the very extent to which families of perpetrators and whole societies are affected in the long term by past crimes (Osofsky, Bandura, and Zimbardo 2005, 371). Also, unquestioning obedience helps individuals to avoid ambiguity at times of transition through what Kelman and Hamilton call "binding forces." Furthermore, a lasting frame of obedience is maintained by the acceptance of leaders' definitions of the situation, ambiguity, and the emotional responses that are triggered by fear (Kelman and Hamilton 1989, 322). In these conditions, individuals are particularly prone to thought reform. Especially because the majority of the staff at S-21 were recruited at a young age, they were by definition fine candidates for the intensive thought reform process that was taking place in the prison. Additionally, given that the moral development of a person occurs last during the person's early adolescence (Kohlberg and Kramer 1969), younger and morally unformed recruits can be turned into violent executioners with greater ease than adults.

In the Cambodian case, the binding forces were the existential threats to the revolution by outside enemies, especially the Vietnamese, the Soviets, and the Americans. In response, a cult of confession took over the entire society. Through one's and others' forced "self-examination," the regime effectively brainwashed segments of the population. This process aimed at the uprooting of what the regime would consider ill habits and intentions as well as the extermination of real and imagined enemies of the state (Chandler 1999; Hinton 1998, 2005; Kiernan 1995). Also, discussions of obedience in the Cambodian setting must be framed within the particular state or society framework where the leader bears moral enlightenment. As such, the leader is an instrument of the correct moral order, the dhamma itself (Garrett-Jones 1979; Hancock 2008, 105). Thus, one is forced to ask whether it was deeply ingrained values in Cambodian society, such as hierarchy, or the effective use of mind control and obedience that led to the enormous number of victims.

In Cambodia's devout Buddhist culture, "a head for an eye" may sound like an odd proposition. Alexander Hinton, in his examination of the cultural antecedents of the KR killing machine, highlighted how norms of revenge played out when one was dishonored or suffered "losing face." Hinton examined the Cambodian legend Tum Teav. In a metaphorical sense, Tum Teav implies that cutting off the rotten branch bears limited results. In its exaggerated dimension, according to Hinton, disproportionate revenge calls for the extermination not only of a single wrong-doer, but his entire family, including children (Hinton 2005). During the genocide, any suspected contrarian mind would be 
exterminated, along with numerous associates and family members. Eve Zucker offered an alternative interpretation of the concept of "face," which Hinton equated with "reputation." Rather than the internal motive of revenge as the motivating factor in the perpetration of genocide, Zucker argues that the public display of gaining face for one's self-preservation and promotion also explains KR cadres' motivation (Zucker 2013, 100-102). ${ }^{3}$

Furthermore, the Buddhist concepts of mindfulness, self-control, and renunciation of the individual self and individual property served as crucial cultural frames for KR thought reform (Hinton 2005, 198; Zucker 2013, 54). "Gaining merit" in the KR hierarchy of power, Zucker (2013) observes, strikingly resembles religious merit in Cambodian culture. In the KR ideology, gaining revolutionary merit requires that one not only perform revolutionary tasks or exhibit competence at work, but also surrender individualism to the Angkar (organization). Other Buddhist concepts of renunciation of selfcontrol and worldly personal ownership were widely employed as a means to present Marxism to a puzzled population. In order to assign culpability, one should not stop with one's actions but also look deeper into underlying motives. The most severe punishment was meted out for the intent to lie, the effort to deceive, and the act of communicating untruth (Hancock 2008, 107; Harris 2013, 106; Keown 2013). Consistent with Buddhist practice, the examination of consciousness became a central pillar of Khmer communism (Harris 2013, 57; Short 2004, 150). As Harris (2013) pointed out, proletarian consciousness could be forged, independent of a person's class origins or economic status.

\section{The Sociocultural Milieu of KR Thought Reform}

The KR leadership drew inspiration from existing norms in cultural traditions in Cambodian society regarding respect, obedience to hierarchy, Buddhist rituals, and revenge. While the majority of $\mathrm{KR}$ cadres were only nominally acquainted with Marxist ideology, they were more familiar with Buddhist ideas and practices, such as subjecting oneself to self-scrutiny. Coupled with these traditional notions, the KR leadership introduced mind control methods that were first developed by the Soviets during the show trials of 1936-38, and later the Chinese reeducation campaigns during the Cultural Revolution. The method of thought reform was first introduced to the KR leadership during the 1950s. At the time, Pol Pot and his associates were studying in France. In the early postwar years, the French Communist Party was closely associated with the Soviet Communist Party. Memories of the purges of the 1930s were still fresh. The type of "justice" the Soviets applied during the purges proceeded initially with sentencing and afterwards with a verdict. Stalin's methods of thought reform found their way to China through K'ang Sheng (1898-1975). After becoming the head of the Chinese Communist Party's security and spying operations, K'ang Sheng oversaw the implementation

\footnotetext{
3"Face," or muk moat in Khmer, can also be taken to represent one's facial composure, which can both make and sustain one's social reputation. Muk moat also protects a person by masking vulnerability. "Gaining face," or yok muk moat in Khmer, is prevalent in Khmer society, where the hierarchical patron-client relationship revolves around power, protection, and status (Zucker 2013, $100)$.
} 
of these methods first during the 1940s and then during the 1960s, when he became a senior ideologue (Lifton 1989, 127).

Echoing China's Cultural Revolution, the KR aimed at eliminating linguistic elements of class, kinship, and social structure. They invoked existing local frames of knowledge that allowed them to relate such external and unfamiliar ideology to their cadres and the masses (Hinton 1998, 115; Lifton 1989, 422). ${ }^{4}$ The purging of the inner self through self-surrender of the individual to his or her environment aimed at maintaining "the revolutionary ethos" (Lifton 1989, 425). Eventually, the culmination of the process involved statements that signaled a "born again" self (66-85). The KR subjected their cadres and the masses to a system of routinized thought reform during criticism and self-criticism or, as they became known, livelihood meetings for the purpose of value self-confrontation (Ea Meng and Sim 2001). In these sessions, the cadres had to regularly produce exhaustive accounts of their inner states, their state of vigilance, and their regard for their mission and specific tasks. These confessions were the mirrors of their inner thinking and served to keep the cadres' minds closely aligned with the revolutionary spirit. Livelihood sessions were frequently used to expose those who were not vigilant enough.

The KR rationale for thought reform was best understood in terms of a self/other nexus, primarily defined by class. The revolutionary "self" included poor peasants and workers who were already members of the Communist Party of Kampuchea (CPK), the highest Angkar. The "other" included those Cambodians who were not party members, those who were trying to stay "under the radar," or others who were seen as unredeemable. Angkar members needed to be vigilant in order to attain and preserve the purity of the Angkar spirit against "germs," such as "capitalists, imperialists, feudalists and anarchists of all kinds" (DC-Cam 1999b).

S-21 was at the forefront of the vigilance battle against the enemies of the Angkar. These enemies could be either internal (hidden among the masses or even the Angkar) or external (associates of bourgeois, Vietnamese, CIA, and KGB elements). Internal enemies from within the Angkar accordingly posed a greater danger than external enemies (DC-Cam 1999a). ${ }^{6}$ This was a state of continuous revolution, fighting internal and external enemies everywhere. The fighting was constant and aimed at many

${ }^{4}$ The Chinese became masters in rectification. K'ang Sheng had learned the process of thought reform in the Soviet Union and brought it to China. Sheng became the head of Mao's secret police and aimed in particular against revisionists (Chandler 1999, 126).

${ }^{5}$ The Yale University-based researchers who translated the text of the diary believe that it belonged to a higher-ranking cadre associated with the Ministry of Defense. The author appears with the alias Khim Vat.

${ }^{6}$ This notebook apparently belongs to an Angkar member and a high-ranking military officer (see also DC-Cam 1975-76b). The notebook contains reflections from a series of study meetings to extract lessons regarding the interrogations at S-21, and particularly discusses how to determine if someone is a CIA operative and how to interrogate detainees to track down CIA networks across the country. During a "study session" in S-21, on January 11, 1976, the author wrote that, in order to determine who was a CIA agent, five aspects of a detainee's life and career ought to be examined: (1) biography; (2) class (education, rank, and social status); (3) career track; (4) family, friends, and social networks; and (5) association with foreign organizations, such as foreign media groups, World Vision, UN organizations, etc. "If true, [and] it [was] 70\%-80\% true, that he or she [would be] a CIA agent." A belief that circulated in S-21 was that there were at least 20,000 Cambodian CIA agents who had already infiltrated the countryside at the 
different levels. Enemies could be found among random citizens or acquaintances, within one's military unit, and even in one's own family. The internal battle was waged most intensely in one's mind, targeting remnants of bourgeois habits, lazy consciousness, or an undeveloped revolutionary self. In this pervasive culture of fear and paranoia, selfpreservation and betterment of one's situation became a moral imperative among the KR cadres (Hinton 1998, 115).

\section{The Cadres' Life at S-21}

Honor in the context of S-21 came from fighting the enemies of the state. Honorable KR activity and gaining revolutionary merit would also ensure that one would not be executed or pushed down in rank where the food was scarcer, the shelter was worse, and one's family could be executed by higher-ranked KR cadres. No one could be trusted, not even the closest associates in the prison system (Maguire 2005, 58). ${ }^{7}$

Duch's sense of discipline was forged by his previous line of employment as a math teacher and his Maoist-inspired ideology. Duch demanded ultimate uniformity from his followers. It is well documented that he was directly involved in every aspect of the institution, including holding political study meetings, providing interrogation training, giving feedback in response to S-21 staff self-criticisms, and checking on the killing of prisoners. During his testimony before the ECCC, S-21 interrogator Larch Mean spoke of frequent political sessions that Duch organized to educate all interrogators about the Angkar line and to teach them interrogation techniques and the proper manner in which interrogations ought to be conducted. ${ }^{8}$

Duch staffed the S-21 with young boys between the ages of eleven and fifteen from the heartland of Cambodia in Kampong Tralach District, Kampong Chhnang Province. He explained in no uncertain terms how he recruited the S-21 staff during prison guard Chun Phal's testimony: "I did not want to select any person who was already trained or educated by anybody. So, I needed to select those I could train psychologically and politically."' Despite Duch's emphasis on his role as the first trainer of his staff, some had already participated in fighting with KR militias against Lon Nol's regime. The final sorting would take place in training grounds, such as Praek Hour. ${ }^{10}$ Nevertheless, from Duch's account it becomes clear that the basis of recruitment was class, origin, and age rather than individual proclivity for violence.

Duch was eager to impress upon the young recruits the revolutionary thinking and their duties. He maintained that even a good revolutionary like Nhem En, the S-21 photographer, had to be forged into an obedient subordinate. Nhem En was from pure peasant stock and was recruited at age ten. He was eager to seek approval from his

time the KR gained victory on April 17, 1975. Their networks were dispatched to live among the masses in the countryside starting in 1973.

${ }^{7}$ According to S-21 records, 563 guards and other personnel of the prison became prisoners and were killed between 1976 and 1979.

${ }^{8}$ Case No. 001/18-07-2007-ECCC/TC, E1/49.1, 61.

${ }^{9}$ Case No. 001/18-07-2007-ECCC/TC, E1/60.1, 64.

${ }^{10}$ Case No. 001/18-07-2007-ECCC/TC, E1/58.1, 2. 
superiors. Duch considered him "a true revolutionary child” (Dunlop 2005, 155). In Dunlop's account, Nhem En himself likened S-21 staff to Buddhist monks who took vows of celibacy, poverty, and moral restraint with a conformity of purpose (156). Another child recruit, Chun Phal, argued: "I was fifteen years old. I just did the assignment."11

As was the case in the Angkar culture, the leading officer had control over the cadres' personal lives. Being introduced to a spouse by the Angkar was not uncommon. Reportedly, Duch himself organized marriages for a few S-21 staff members. During the authors' interview with Larch Mean, he reflected back on his association with Duch, saying: "I thought that Duch would get me a wife."12 Marriage during the KR regime, however, could come with perils. Senior guard Him Huy testified: "During that time, anyone who got married would be more vulnerable to being arrested." ${ }^{3}$ What Huy meant was that if the spouse of an S-21 staff member was implicated in any way, then he too could be arrested.

\section{Work at S-21: Interrogating Prisoners and Oneself}

However, the goal of each KR cadre was transformation through eradication of impure and corrupt thinking patterns. Seeking to correct himself, one of KR cadres initially stated his prior lack of vigilance as follows: "I did not tightly grasp the essence of the proletarian class ... and [did not use] it as a guiding principle of my actions...." The cadre went as far as exposing himself for feeling pity after one of his fellow cadres was considered to be a traitor. He argued: "Concerning the arrest of a traitor in my unit, I still felt pity for him because I used to live with him and never saw any of his behaviors which convinced me to see him as a traitor" (DC-Cam 1976, 1999a). After the cadre completed his self-criticism, he added in the notebook his fellow comrades' criticism of him. One of this cadre's evaluators, comrade Srun, responded to the cadre's self-confession and chastised him as follows: "You did not pay enough attention to root out traitors in your unit. You just stick to your duty, but do not care about other tasks in the Ministry" (10). Finally, the cadre's superior, referred to as "Angkar," reviewed the entire critique and concluded: "Regarding your leadership, you do not fully understand the essence of revolutionary politics, assignment and conscience.... You failed to see the treacherous activities of traitors in your unit. Your leadership is weak in terms of governing the mass and conducting livelihood meetings" (12). The cadre added that the leadership was pleased with how the self-criticism meeting was conducted and encouraged continuing self-criticism and criticism to eliminate private ownership (12-13).

In one of the self-criticism meetings, senior guard Him Huy, who was also in charge of transporting prisoners to the killing site Cheung Ek, described his "shortcomings" in his self-critical autobiography as follows:

\footnotetext{
${ }^{11}$ Chun Phal, interview with the authors, Cambodia, March 18, 2010.

${ }^{12}$ Larch Mean, interview with the authors, Cambodia, March 18, 2010.

${ }^{13}$ Case No. 001/18-07-2007-ECCC/TC, E1/51.1, 22.
} 
I speak impolitely to my fellow Comrades, horse around a lot, [and] I am easily offended and quick in anger... My leadership of the masses has not been passionate. As a result of which the masses doing guard duty have been negligent, as a result of which enemies have been able to escape or seize weapons and kill themselves. ${ }^{14}$

Self-criticism was also conducted at the top of the S-21 apparatus, including Duch and his deputy Mam Nai, alias Chan, senior interrogator for Vietnamese prisoners (Dunlop 2005, 131). In his diary, Mam Nai reports that the group meetings took place every evening in Duch's presence (DC-Cam 1975-76, 12-15; 1999a). However, at such a high level the tone was rather celebratory. For example, Mam Nai wrote in his confession: "I was a former professor. I was in the bourgeoisie class, and then I rebuilt myself to adapt myself into the proletarian class, into the workers class, and I achieved that. And that is the reason why the revolution allowed me to be a member of the Angkar."15

The surviving forty-plus-page S-21 Interrogators' Manual revealed a meticulous interrogation process. It incorporated "study meetings" and "self-criticism and criticism sessions" as a central means of enhancing the efficiency of interrogation. For example, in a "study meeting," Duch raised the issue of interrogators' excessive use of torture instead of "doing politics" (thvoe noyobai) (DC-Cam 1999a). The interrogators forced prisoners to drink alcohol, and laughed at prisoners during the interrogations. In the manual, Mam Nai reported Duch's advice as follows:

The trick is to make the prisoners feel that they should not be afraid of admitting mistakes because it is only a person who does not reform [that] is a threat to the revolution. In this vein, one has to prevent the prisoners from feeling hopeless or that they would not get out of S-21 alive. The goal is to dig out networks of CIA agents. (DC-Cam 1999a)

In a livelihood meeting dated March 3, 1976, Duch expressed his displeasure with the interrogation work by noting that "prisoners were able to conceal their biography, their [treacherous] plan and networks" (DC-Cam 1975-76b, 68). Duch attributed this trend to the interrogators' weak revolutionary consciousness. He instructed the interrogators to conduct frequent "interrogation lessons" that were in essence self-criticism meetings intended to strengthen interrogators' "absolute revolutionary standpoint and consciousness" (69). If a cadre survived the harsh treatment, including self-criticism, for long enough, he would have the opportunity to advance to a position of greater authority and increased responsibilities. It would typically take three months of training for a guard to become an interrogator. The training involved watching other interrogators at work. This work included having the prisoners write down their confessions. Interrogations would take place twelve hours a day.

\footnotetext{
${ }^{14}$ Ibid., $13-14$.

${ }^{15}$ Case No. 001/18-07-2007-ECCC/TC, E1/48.1, 59; DC-Cam 1975-76a. Mam Nai noted this in a meeting on December 23, 1975.
} 


\section{Reflecting on the Past: Lingering Manifestations of Obedience among S-21 Personnel}

The persistence of ideological and moral frames among S-21 personnel of all ranks is apparent in how they relate to the past today. This persistence is reflected in their reasoning for their actions during the regime and their subsequent self-assessment of what has transpired. Most cadres continue to define the reasons for Cambodia's KR takeover using KR terminology. Furthermore, the cadres' assessment of the past demonstrates selfvictimization, justification for the orders they obeyed during their work at S-21, limited empathy toward their victims, and continuing heroization of the role they played. A most telling indication of the obedient frame of mind is the disavowal of responsibility across the ranks.

Duch's subordinate, senior interrogator Larch Mean, still believes that the people he interrogated were "enemies" and therefore rationalizes his dutiful role in his past actions. Over the years, senior guard Him Huy has constructed a nearly consistent narrative of being "a victim" of powerful forces beyond his control at S-21, and therefore denies his agency at this infamous institution where he aided and directly participated in the mass atrocities. Him Huy shared that the cadres at S-21 were in constant fear for their lives and concerned about carrying out their tasks meticulously in order to avoid being taken away and killed. ${ }^{16}$ With regard to how it was being in the same room with Duch, former S-21 guard Chiem Seour said:

I was chilled to see Duch there because I remembered how powerful he was at S-21. I was so nervous to see him for the first time in the court. I never saw him when I was in S-21 because I was a guard outside S-21. I only knew that he was the chief then. When the judge called him by "the accused" and I saw court policemen escort him in, I did not fear him anymore. ${ }^{17}$

For his part, Duch was aware of the impact he had on S-21 personnel. During his trial, he mentioned during Chun Phal's testimony that when "[o]bserving the psychology of Comrade Phal—, he did not even want to see my face or to hear my voice. And that view impressed me that he was staff of S-21."18

Duch's subordinate, senior guard Him Huy, perhaps one of the most vocal among all former S-21 cadres, has gone back and forth about his own involvement in S-21. Huy represents his innocence and victimhood during his tenure at S-21 as involving serious wrongdoings and completely denies his responsibility for the atrocities. During the authors' interview with Him Huy in June 2009, just two months before he testified in the ECCC hearings against Duch, he shared the following exchange with Duch:

\footnotetext{
${ }^{16}$ Him Huy, interview with the authors, Cambodia, June 8, 2009.

${ }^{17}$ Chiem Seour, interview with the authors, Cambodia, March 17, 2010.

${ }^{18}$ Case No. 001/18-07-2007-ECCC/TC, E1/60.1, 64.
} 
Author: Were you ever ordered to take part in the executions?

Huy: Yes, I did. One time Duch was there. There was only one prisoner left. He said to me, "Comrade, would you dare to kill? Are you absolute?" So I took the iron bar and clubbed him, then threw down the bar and walked away.

Author: Did you ever think about them?

Huy: I felt there was no escape; I felt like my days were numbered, there was no escape.

Huy made a similar acknowledgment in the 2007 DC-Cam documentary film entitled Behind the Walls of S-21 (Kass 2007). However, during his testimony against his former boss, Duch, Him Huy repeatedly refused to admit any involvement in the killings and tortures. ${ }^{19}$ Instead, he argued that in S-21 he lived in "constant fear for his life" to the point that he denied Duch's offer of a woman as his wife because he did not want her to suffer as he contemplated his arrest at S-21. Him Huy argued that he had helped prisoners who could not walk to get onto the trucks before his unit transported them to the killing site. ${ }^{20}$ Against Him Huy's narrative of innocence, survivor of S-21 Bou Meng testified that Him Huy beat him regularly. Him Huy, however, when confronted at the court about his mistreatment of prisoner Bou Meng, denied any mistreatment and only admitted to riding on Bou Meng's shoulders to test his strength. ${ }^{21}$ During his interview with the authors, one year after his ECCC testimony, Him Huy responded regarding how he felt overseeing the killings of the prisoners as follows: "I did not feel anything."

When asked about whether he liked his job at S-21, Him Huy replied: "I was satisfied with my work to stand guard because I had to fulfill my work to reconstruct myself in order to survive." Him Huy was referring here to the reconstruction of his thought process according to the Angkar standards that were applied at S-21 and elsewhere among cadres. When asked how he felt about Duch's trial, Him Huy said: "I feel at peace that Duch was tried and convicted by the court. He attempted to take my life." ${ }^{22}$ For his part, Duch recalled Him Huy as one of his most trusted cadres at S-21. ${ }^{23}$

Vann Nath, an S-21 survivor, recalled in his memoir that Him Huy was like "a savage bull, a lion. None of the prisoners, including myself, had dared to look him in the face then. Now, he was in a deadlock, with no more fangs or horns. Seeing him in this situation, somehow I felt pity for him" (Hinton 2013, 13; Maguire 2005, 129). S-21 survivors like Bou Meng and Van Nath claimed that Him Huy was also one of the executioners.

Similarly to Him Huy, Larch Mean, a senior interrogator at S-21, still seems to believe that with his work in the prison, he did his soldierly duty to serve the country. In an interview, Larch Mean spoke proudly of being one of the best interrogators at S-21. He told the interviewer that sometimes he was given one or two days to extract confessions from prisoners, but Larch Mean would decide to interrogate prisoners throughout the night to extract a confession for his superior by the morning (DC-Cam 2002). As

${ }^{19}$ Case No. 001/18-07-2007-ECCC/TC, E1/51.1, 22.

${ }^{20} \mathrm{Ibid}$.

${ }^{21}$ Ibid., 45 .

${ }^{22}$ Him Huy, interview with the authors, Cambodia, June 8, 2009.

${ }^{23}$ Case No. 001/5-08-2009-ECCC/TC, E1/54.1, 22. 
he recalled: "I [could] use whatever means I wanted to get the confession, but I [could] extract confessions without having to torture prisoners" (DC-Cam 2002). In the court, he consistently denied any mistreatment of prisoners, let alone torture. Larch Mean admitted that he would report the prisoners who refused to confess to his superior Khim Vat (alias Hor) for further actions. In his ECCC testimony, Larch Mean asserted that he did not believe that these prisoners were enemies of the Angkar, but that the staff were told to regard them as enemies. He gave an example of the arrest of his unit chief. He said his chief did a good job at S-21 and he did not believe that he was a traitor. ${ }^{24}$

Less than a year after his ECCC testimony, the authors asked Larch Mean if he thought the prisoners were telling the truth. He replied: "Some actually did what they confessed and some did so because they were in great pain." Mean added that "there were some good people and there were some people who committed wrongdoings and, through my observation, there were less good people than the bad people. So I am regretful for those small groups of good people." However, he also argued that at that time he believed that among these detainees sent to S-21, there were in fact "many real hidden enemies" because there was evidence in the confessions of the details as to their leadership, the swearing of allegiance, and the locations where they allegedly joined CIA, KGB, and Vietnamese agents. ${ }^{25}$

The majority of the S-21 personnel did not express emotional ties with the victims. They either did not include expressions of grief about the victims or they would defer responsibility to their superiors. Low-ranked S-21 cadres such as Chiem Seour, Chun Phal, and child-medic Sek Dan conceded in general terms that what happened was "regrettable," but revisiting an old trauma "did not make sense." In these cases, the interviewees went on to dramatize their sadness, loss of family connection, and fear for their lives during the years they had worked in the conditions of S-21 rather than expressing any empathy for the prisoner population. They also appeared disassociated from the victims of torture and displeased with their work. In this vein, interrogator Larch Mean stated: "I feared for my life at all times because [other cadres] were arrested and killed." 26 During our interview, Mean said about his work: "I did not think much of it," and "it was kind of a boring job.",

The guards tended to express relief after their participation in the ECCC hearings was over. Finally, they knew they would not be prosecuted for their testimonies. Also, they would not have to hide their participation from neighbors or family any longer. In Phal's words:

I never told anyone. I hid it from the authorities. Only recently, the Documentation Center of Cambodia found out my identity and wanted to interview me. I was convinced that my story will help reveal the truth to prevent such a regime should never happen again. Personally, I do not want my family to know about it. I do not want to dig into the past because who would care about it anyway. I kept

\footnotetext{
${ }^{24}$ Case No. 001/18-07-2007-ECCC/TC, E1/53.1.

${ }^{25}$ Larch Mean, interview with the authors, Cambodia, March 18, 2010.

${ }^{26}$ Case No. 001/18-07-2007-ECCC/TC, E1/55.1, 83.

${ }^{27}$ Larch Mean, interview with the authors, Cambodia, March 18, 2010.
} 
this secret to myself. I reflected on it sometimes that the regime was too extreme. $^{28}$

But, when it came to discussing Duch's sentence, the interviewees were reluctant to assign blame and instead proposed lesser sentences than the actual term that Duch received. Much like the other former S-21 cadres, Chiem Seour and Chun Phal did not want to assign responsibility for what happened in S-21. They appeared to believe that Duch too received orders from the KR leadership. Phal did not want to judge who was responsible overall for what happened in S-21. He argued, "I don't know. It is up to the ECCC." ${ }^{29}$ In Phal's mind, if one follows orders, then one is exempt and should be left out. This would be the case even if one was ordered to kill a person. Regarding our question about who is to judge (and therefore reflect upon such actions), Phal argued, "the ECCC [is] to judge." 30 S-21 medic Sek Dan stated his assessment of Duch's culpability: "If Duch just followed orders ... [he] is not guilty. If I were in his shoes, I would do the same. Of course, the actions were wrong, immoral. But another equation is that he also followed orders from above."31

In his own testimony, Duch also claimed that he was following orders. He argued that he had to report daily to Son Sen, deputy prime minister in charge of national defense, about the outcome of the interrogations. Duch stated: "In my mind, I was still believing that I was a policeman who was carrying out the order assigned to me by my superior, and this is how I developed my mentality regarding the crime and criminal responsibility." 32

Through a nonspecific acknowledgment of guilt, and a public apology to the victims in the court for his role in the KR, Duch sought to provide the frame for others to judge him. This expression of responsibility served what he called "the humanitarian aspect," which entailed having to take responsibility as a KR agent for those Cambodians who died under the KR. Apparently, he sought to attach his culpability to his identity as someone high in the KR echelon, because, as he proclaimed, "one [sic] million people died” during the KR. As David Chandler $(1999,36)$ argues, Duch, by aggrandizing his responsibility and attaching it to the total number of deaths during the KR rather than the approximately 14,000 deaths connected with S-21, he also sought to diffuse it. By the same token, Duch claimed that he too needed to be "reconstructed." 33

An example of Duch's indirect culpability self-assessment was given during Mam Nai's court appearance. Duch brought up the case of S-21 associate Chao Seng, who was eventually purged. In Mam Nai’s presence, Duch recalled when Chao Seng, in a lapse of "bourgeois argumentation," chastised Prince Norodom Sihanouk's French as

${ }^{28}$ Chun Phal, interview with the authors, Cambodia, March 18, 2010.

${ }^{29} \mathrm{Ibid}$.

${ }^{30} \mathrm{Ibid}$.

${ }^{31}$ Sek Dan, interview with the authors, Cambodia, March 17, 2010.

${ }^{32}$ Case No. 001/18-07-2007-ECCC/TC, E1/76.1, 3, 5. Duch's account here bears similarity with that of Franz Stangl, the Commandant of Treblinka. During his interview with Gitta Sereny, Stangl argued: "It was matter of survival, always of survival. What I had to do, while I continued my efforts to get out, was to limit my own actions to what I-in my own conscience-could answer for" (Sereny 1974, 164).

${ }^{33}$ Case No. 001/18-07-2007-ECCC/TC, E1/49.1, 69. 
inferior "even of that of the King of Arabie Soudite." Then, addressing Mam Nai directly, Duch added: "Chao Seng was left to be with you, although I got the order from the upper echelon to have him smashed." 34

Duch was sentenced to thirty-five years in prison at his initial trial. That sentence was reduced to nineteen years after taking into account the years he had already been in prison, and there was an additional five-year reduction in reparation for having been detained prior to the establishment of the ECCC. As became obvious during Duch's trial, his staff and collaborators engaged in whitewashing their individual responsibility and covered up the truth of their actions.

When it came to anticipating or evaluating Duch's sentence, the interviewees were reluctant to assign blame. Instead, they would counter-propose lesser sentences than the actual term that Duch received. Most S-21 cadres argued that Duch was too old for a long sentence. S-21 interrogator Larch Mean argued that ten to fifteen years would be enough for Duch. ${ }^{35}$ Another respondent, Kong Chhorn, a former monk who was defrocked by the KR but then served at S-21, argued that "it would be up to the ECCC and the collective $[\mathrm{sic}]$ to decide on who is responsible." He added that Duch was too old for a long sentence. When asked if the guards ever thought of opposing any Angkar policy, the predominant answer was: "If the government laid down such a policy then we should follow." The given reason was: "If I did not obey, they would take me away." 36

For the most part, the guards expressed satisfaction about the ECCC. They regarded it as a legitimate forum for the deliberation of justice. Almost uniformly, they responded that it would be up to the ECCC—not them — to condemn Duch. Some added the government as another source to deliberate about justice. With regard to their actions, Phal argued that "guilt exists only when one is not threatened." 37 Thus, the nullification of guilt occurs due to the simultaneous threat by a higher authority. According to Mean, the ECCC would achieve justice given the large number of questions he had to answer. Reflecting on how he felt after the end of his testimony, Mean argued that he "felt normal ... not so much happy-afraid no more. ${ }^{\text {38 }}$ When asked if he enjoyed being a guard and interrogator at S-21, Mean said:

I think it is hard for me to say that I was satisfied with the work at that place because it was a kind of boring job and we had no freedom to move about freely, and we had to be very careful because any mistake we committed would result in the punishment. So we worked too hard and we lived with fear, and we thought that one day we would end up being killed as the other detainees. However, it was the assignment assigned by the upper-ups, upper echelon, so we had to abide by these orders. ${ }^{39}$

\footnotetext{
${ }^{34}$ Ibid.; emphasis added.

${ }^{35}$ Larch Mean, interview with the authors, Cambodia, March 18, 2010.

${ }^{36}$ Kong Chhorn, interview with the authors, Cambodia, March 19, 2010.

${ }^{37}$ Chun Phal, interview with the authors, Cambodia, March 18, 2010.

${ }^{38}$ Larch Mean, interview with the authors, Cambodia, March 18, 2010.

${ }^{39}$ Case No. 001/18-07-2007-ECCC/TC, E1/57.1, 52.
} 
Then he was asked: "If you did not enjoy or like working there, why didn't you find a way to escape?" Similarly to Him Huy, Larch Mean replied: “There was no other option, no other way. We had no opportunity to contact any outsiders, let alone finding any other possible means to escape. So instead we had to commit ourselves to working hard to gain favor from our superiors." ${ }^{40}$ Larch Mean mentioned that although he regretted working at S-21, he qualified his "regret" on the basis of work conditions. He said: "The work was horrendous, exhaustive. We walked on patrol for long hours; sometimes I walked into a wall. I felt disappointed at the work that I did at S-21. And it is my regret that I worked there in long hours. ${ }^{41}$ For prison clerk Suos Thy, fear was the predominant emotion. He argued: "I was so scared of my immediate supervisor, let alone Duch, so even the cadres who worked with Duch they did not even call them by names. They just addressed them by using 'Brother East' or 'Brother' and that's all. And it was the reality back then." ${ }^{\text {"2 }}$

During his trial, Duch himself declared that he thought the KR would not be defeated and he saw a place for his children in the revolution. He maintained:

I did not really like the police work. However, I was in amongst the candidate members, or the members of the Angkar who had nowhere to escape. So I already indicated that we were the actors of the crimes and trapped in the system.... I was part of the gear of the machine. And I would like my children to be part in the revolution, but although I knew that it was part of crimes, ... I could not escape. I never envisaged that CPK would be defeated any day. ${ }^{43}$

After the KR fell in 1979, Duch fled to the Amleang region and disappeared from public view. Under the pseudonym Hang Pin, he went on to get a job as a teacher and then as a volunteer assisting refugees. He was discovered in 1999 by photojournalist Nic Dunlop in the village of Andao Hep in Rattanak Mondul, working for the American Refugee Committee. He had in the meantime converted to Christianity and become a lay pastor (Dunlop 2005, 249). He was said to be meticulous with his religious duties, studious, and a thorough student of the Bible. His fervor trying to spread his new faith among colleagues, family, and neighbors could have been patterned after his revolutionary days as an exemplary KR agent. The expert psychologist Françoise Sironi-Guilbaud, who examined him upon ECCC request, argued that for Duch "God [had] replaced communism. God, Jesus represent[ed] a new ideal." At the court, Sironi-Guilbaud testified that "dis-empathy [was] present in Duch who killed in himself any kind of personal identity to the benefit of a ... common ideal."

\section{Conclusion}

In summary, through an intense thought reform program, the S-21 personnel were continuously forged as obedient functionaries of the killing machine to carry out mass

\footnotetext{
${ }^{40}$ Ibid.; emphasis added.

${ }^{41}$ Ibid., 62.

${ }^{42}$ Case No. 001/18-07-2007-ECCC/TC, E1/55.1, 64.

${ }^{43}$ Case No. 001/18-07-2007-ECCC/TC, E1/76.1, 3.

${ }^{44}$ Case No. 001/18-07-2007/ECCC/TC E21.1, 36.
} 
atrocities. Cambodia's culture of obedience, respect for hierarchy, and norms of revenge, as well as the purposeful recruitment of unformed youth with limited education from farming communities, allowed Duch to forge these recruits into fearful and utterly obedient functionaries of the regime. In this climate, the staff learned to maintain psychological detachment from prisoners, and did their utmost to gain favor from the upper echelons by exhibiting loyalty and competence at work. The S-21 personnel were far more concerned about their self-preservation and standing among their peers and in the eyes of their superiors than their human connection with the prisoners. Their obedience orientation has lasted till today.

Lack of moral confrontation, and the limited reflection of the former S-21 staff, underline the powerful effects of induced obedience decades after the fact. By employing the systematic tools of mind control, constant surveillance of one another, and celebration of the spirit of the revolution, young recruits from rural Cambodia were turned into obedient servants of the KR establishment of terror. The avoidance of self-condemnation has been pervasive among the S-21 personnel. As we discovered during our interviews, the cadres' enmeshment in their roles has endured for decades after the fall of the KR in 1979.

While the legacy of S-21 is horrifying in its own right, it is far from isolated. Besides S-21, the KR regime established 196 prisons, surrounded by more than 19,773 mass graves throughout Cambodia (Documentation Center of Cambodia, n.d.). The KR system of terror involved thousands of middle- and low-level cadres who followed the Angkar policy of mass killings. They were active perpetrators in the KR machinery of destruction and now coexist with often unsuspecting survivors across the country (Heder 2005). The rehabilitation of former perpetrators remains rare, and many former perpetrators still live in tight-knit ex-Khmer Rouge communities in former KR strongholds, such as Pailin and Anlong Veng. In fact, narratives of heroization (mostly in the fight against the Vietnamese), revolutionary comradeship, and sacrifice for their revolutionary cause are typical within "insiders' discussions" among former KR cadres and in their family settings.

The social influence of the KR "terminal solution" morality may be long void of revolutionary elements, but it still persists among the S-21 personnel and perhaps other KR cadres. One must delineate the top-down idleness in Cambodia and geopolitical interests for the delayed sanctioning of the KR leadership. In comparison to the ECCC, which commenced officially in 2009, the International Criminal Tribunal in Rwanda (ICTR) was established in November 1994, months after the Rwandan Genocide in April 1994. Despite criticism, the ICTR indicted ninety-three individuals and convicted sixty-one, whereas the ECCC indicted five and convicted three of the highest-ranking KR leaders. Many in the lower echelons were left alone and never held accountable. At the social level, the process of transitional historical justice has just begun. It requires the nation's sustained efforts to conduct an open-ended historical inquiry, and a broader and deeper historical accounting, including the truth from "small fish" perpetrators. Unfortunately, the KR perpetrators and collaborators, as genocide researcher and survivor Youk Chhang (2007) has observed, are "the thieves of Cambodia's history." 


\section{Acknowledgments}

The authors would like to thank Jeff Wasserstrom and the anonymous reviewers of the Journal of Asian Studies for their comments. Thanks also to the Interdisciplinary Center for the Scientific Study of Ethics and Morality at the University of California, Irvine, and the Director of the Center, Kristen Monroe; Bruce T. Murray; Art Blaser; Robert Green; the Documentation Center of Cambodia and the Director of the Center, Youk Chhang for allowing access to the material of the Center; and the Shoah Foundation at the University of Southern California and the Center for Khmer Studies for funding support.

\section{List of References}

Browning, Christopher R. 1992. Ordinary Men: Reserve Police Battalion 101 and the Final Solution in Poland. New York: Harper Collins.

Chandler, David. 1999. Voices from S-21: Terror and History in Pol Pot's Secret Prison. Berkeley: University of California Press.

ChHang, Youk. 2007. "The Thief of History-Cambodia and the Special Court." International Journal of Transitional Justice 1(1):157-72.

Documentation Center of Cambodia. n.d. "Mapping Project, 1995-Present." www.d. dccam.org/Projects/Maps/Mapping.htm (accessed December 17, 2016).

Dunlop, Nic. 2005. The Lost Executioner: A Story of Comrade Duch and the Khmer Rouge. London: Bloomsbury Publishing.

Ea Meng, Try, and Sorya Sim. 2001. Victims and Perpetrators? Testimony of Young Khmer Rouge Comrades. Phnom Penh: DC-Cam.

Ferguson, Christopher, and Kevin Beaver. 2009. "Natural Born Killers: The Genetic Origins of Violence.” Aggression and Violent Behavior 14(5):286-94.

Garrett-Jones, John. 1979. Tales and Teachings of the Buddha: The Jataka Stories in Relation to the Pali Canon. London: George Allen \& Unwin.

Hancock, Virginia. 2008. "No-Self' at Trial: How to Reconcile Punishing the Khmer Rouge for Crimes Against Humanity with Cambodian Buddhist Principles." Wisconsin International Law Journal 26(1):87-129.

Haritos-Fatouros, Miкa. 2003. The Psychological Origins of Institutionalized Torture. London: Routledge.

Harris, Ian. 2013. Buddhism in a Dark Age: Cambodian Monks under Pol Pot. Honolulu: University of Hawai'i Press.

Heder, Steven. 2005. "Reassessing the Role of Senior Leaders and Local Officials in Democratic Kampuchea Crimes: Cambodian Accountability in Comparative Perspective." In Bringing the Khmer Rouge to Justice: Prosecuting Mass Violence before the Cambodian Courts, eds. Jaya Ramji-Nogales and Beth Van Schaack, 377-423. Lewiston, N.Y.: Edwin Mellen Press.

Hinton, Alexander Laban. 1998. "Why Did You Kill?: The Cambodian Genocide and the Dark Side of Face and Honor.” Journal of Asian Studies 57(1):93-122. 2005. Why Did They Kill? Cambodia in the Shadow of Genocide. Berkeley: University of California Press.

— 2013. "Justice and Time at the Khmer Rouge Tribunal: In Memory of Vann Nath, Painter and S-21 Survivor." Genocide Studies and Prevention: An International Journal 8(2):7-17. 
Hirsch, Herbert. 1995. Genocide and the Politics of Memory: Studying Death to Preserve Life. Chapel Hill: University of North Carolina Press.

Kass, Doug, dir. 2007. Behind the Walls of S-21. Documentary film. Phnom Penh, Cambodia: DC-Cam.

Kelman, Herbert, and V. Lee Hamilton. 1989. Crimes of Obedience: Toward a Social Psychology of Authority and Responsibility. New Haven, Conn.: Yale University Press.

Keo, Dacil, and Yin Nean. 2011. Fact Sheet: Pol Pot and His Prisoners at Secret Prison S-21. Phnom Penh: DC-Cam.

Keown, Damien. 2013. "Some Problems with Particularism." Journal of Buddhist Ethics 20:445-61.

Kiernan, Ben. 1995. The Pol Pot Regime: Race, Power, and Genocide in Cambodia under the Khmer Rouge, 1975-79. New Haven, Conn.: Yale University Press.

Klee, Ernst, Willi Dressen, and Volker Riess, eds. 1991. The Good Old Days: The Holocaust as Seen by Its Perpetrators and Bystanders. New York: Free Press.

Kohlberg, Lawrence, and Robert Kramer. 1969. "Continuities and Discontinuities in Childhood and Adult Moral Development.” Human Development 12(2):93-120.

Lifton, Robert Jay. 1989. Thought Reform and the Psychology of Totalism: A Study of "Brainwashing" in China. Chapel Hill: University of North Carolina Press.

Maguire, Peter. 2005. Facing Death in Cambodia. New York: Columbia University Press.

Milgram, Stanley. 1974. Obedience to Authority: An Experimental View. New York: Harper Perennial.

Osofsky, Michael, Albert Bandura, and Philip G. Zimbardo. 2005. "The Role of Moral Disengagement in the Execution Process." Law and Human Behavior 29(4): 371-93.

Path, Kosal, and Angeliki Andrea Kanavou. 2015. "Converts, Not Ideologues: The Khmer Rouge Practice of Thought Reform in Cambodia, 1975-1978.” Journal of Political Ideologies 20(3):304-32.

Sereny, GitTa. 1974. Into that Darkness: An Examination of Conscience. New York: Random House.

Short, Philip. 2004. Pol Pot: Anatomy of a Nightmare. New York: Henry Holt.

Sonis, Jeffrey, James L. Gibson, Joop T. V. M. de Jong, Nigel P. Field, Sokhom Hean, and Ivan Komproe. 2009. "Probable Posttraumatic Stress Disorder and Disability in Cambodia: Associations with Perceived Justice, Desire for Revenge, and Attitudes Toward the Khmer Rouge Trials." JAMA 302(5):527-36.

VAn Dijk, Teun A. 2001. "Multidisciplinary CDA: A Plea for Diversity." In Methods of Critical Discourse Analysis, eds. Ruth Wodak and Michael Meyer, 95-120. London: Sage Publications.

Waller, James. 2007. Becoming Evil: How Ordinary People Commit Genocide and Mass Killing. Oxford: Oxford University Press.

Wilson, Margo, and Martin Daly. 1985. “Competitiveness, Risk Taking, and Violence: The Young Male Syndrome.” Ethology and Sociobiology 6(1):59-73.

Zimbardo, Philip. 2008. The Lucifer Effect: Understanding How Good People Turn Evil. New York: Random House.

Zucker, Eve M. 2013. Forest of Struggle: Moralities of Remembrance in Upland Cambodia. Honolulu: University of Hawai'i Press. 


\section{Archival Sources}

DC-Cam (Documentation Center of Cambodia). 1975-76a. Mam Nai’s Self Confession. D15375, 12-15.

. 1975-76b. Meeting Notebook, Tuol Sleng 5047 1999. December 18, 1975 to February 28,1976 . D15375.

—. 1976. "Youth League Meeting." December. D21569.

. 1977a. Revolutionary Army of Kampuchea General Staff. "Joint Statistics of Armed Forces-March 1977.” April 7. L00065.

— 1977b. Revolutionary Army of Kampuchea General Staff. "Statistics of Collective Eating Forces-March 1977.” April 7. L00066.

1999a. Notebook No. 073. S-21 Interrogators' Manual. D21936.

—. 1999b. Notebook No. 074. D21568.

—. 2002. Larch Mean. Interview by Osman Tisa. May 16. K09319. 